\title{
A Phylogenetic and Taxonomic Study on Xylodon (Hymenochaetales): Focusing on Three New Xylodon Species from Southern China
}

\author{
Meng-Han Qu ${ }^{1,2}$, Dong-Qiong Wang ${ }^{1,3}$ and Chang-Lin Zhao ${ }^{1,3,4,5, *(D)}$ \\ 1 Key Laboratory for Forest Resources Conservation and Utilization in the Southwest Mountains of China, \\ Ministry of Education, Southwest Forestry University, Kunming 650224, China; \\ fungimenghanq@163.com (M.-H.Q.); fungidongqiong@163.com (D.-Q.W.) \\ 2 College of Forestry, Southwest Forestry University, Kunming 650224, China \\ 3 College of Biodiversity Conservation, Southwest Forestry University, Kunming 650224, China \\ 4 Yunnan Key Laboratory for Fungal Diversity and Green Development, Kunming 650201, China \\ 5 School of Life Sciences, Tsinghua University, Beijing 100084, China \\ * Correspondence: fungi@swfu.edu.cn
}

Citation: Qu, M.-H.; Wang, D.-Q.; Zhao, C.-L. A Phylogenetic and Taxonomic Study on Xylodon (Hymenochaetales): Focusing on Three New Xylodon Species from Southern China. J. Fungi 2022, 8, 35. https://doi.org/10.3390/jof8010035

Academic Editors: Vladimír Antonín and Hana Sevcikova

Received: 2 December 2021

Accepted: 29 December 2021

Published: 30 December 2021

Publisher's Note: MDPI stays neutral with regard to jurisdictional claims in published maps and institutional affiliations.

Copyright: (C) 2021 by the authors. Licensee MDPI, Basel, Switzerland. This article is an open access article distributed under the terms and conditions of the Creative Commons Attribution (CC BY) license (https:// creativecommons.org/licenses/by/ $4.0 /)$.

\begin{abstract}
Three wood-inhabiting fungal species, Xylodon laceratus, X. montanus, and X. tropicus spp. nov., were collected from southern China, here proposed as new taxa based on a combination of morphological features and molecular evidence. Xylodon laceratus is characterized by the resupinate basidiomata with grandinioid hymenophore having cracked hymenial surface, and ellipsoid basidiospores; $X$. montanus is characterized by the annual basidiomata having the hard, brittle hymenophore with cream hymenial surface, and ellipsoid to broadly ellipsoid basidiospores (3.9-5.3 × 3.2-4.3 $\mu \mathrm{m})$; and $X$. tropicus is characterized by its grandinioid hymenophore with buff to a pale brown hymenial surface and subglobose basidiospores measuring 2-4.8 $\times 1.6-4 \mu \mathrm{m}$. Sequences of ITS and nLSU rRNA markers of the studied samples were generated, and phylogenetic analyses were performed with maximum likelihood, maximum parsimony, and Bayesian inference methods. The ITS+nLSU analysis of the order Hymenochaetales indicated that the three new species clustered into the family Schizoporaceae, located in genus Xylodon; based on further analysis of ITS dataset, X. laceratus was a sister to X. heterocystidiatus; X. montanus closely grouped with X. subclavatus and X. xinpingensis with high support; while X. tropicus was retrieved as a sister to X. hastifer.
\end{abstract}

Keywords: biodiversity; Hyphodontia s.l.; molecular systematics; white-rot fungi; macro-fungi; Yunnan-Guizhou Plateau

\section{Introduction}

Wood-inhabiting fungi are noteworthy components of woody plant ecosystems and take an active part in the decomposition and turnover of nutrients from wood, in which the corticioid fungi are one of the major groups of wood-inhabiting Basidiomycota [1]. Hymenochaetales is one of the most important orders in Basidiomycota because many species in this order are medicinal fungi, and some of them are forest pathogens [2]. Within Hymenochaetales, commonly accepted families Chaetoporellaceae, Coltriciaceae, Hymenochaetaceae, Hyphodontiaceae, Neoantrodiellaceae, Nigrofomitaceae, Oxyporaceae, and Schizoporaceae are supported as individual monophyletic lineages [3]. Schizoporaceae was introduced by Walter Jülich with Schizopora Velen. as the type genus and included the other three genera Fibriciellum J. Erikss. \& Ryvarden, Fibricium J. Erikss. and Fibrodontia Parmasto [4].

The genus Xylodon (Pers.) Gray (Schizoporaceae, Hymenochaetales), with the generic type X. quercinus (Pers.) Gray is characterized by the basidiomata having a smooth, tuberculate, grandinioid, odontioid, coralloid, irpicoid or poroid hymenophore, and a monomitic, 
pseudodimitic or dimitic hyphal system with clamped generative hyphae and mostly presence of 1 to 3 types cystidia, negative in Melzer's reagent; barreled clavate or suburniform basidia, and globose to ellipsoid to cylindrical basidiospores, additionally causing a white rot $[5,6]$. It is the largest segregate genus of Hyphodontia J. Erikss. s.l. (Hymenochaetales, Basidiomycota) based on the MycoBank database (http: / / www.MycoBank.org, accessed on 30 November 2021) and the Index Fungorum (http:/ / www.indexfungorum.org, accessed on 30 November 2021), both have registered 206 specific and infraspecific names in Xylodon, but the actual number of species reaches eighty-six [7-32].

The researches of Xylodon based on molecular systematics are coming to light from genomic analyses and environmental DNA surveys [33]. Species diversity of Hyphodontia sensu lato has been systematically surveyed in Europe for the last several decades, in which almost all taxonomic studies did not try to address the taxonomic status of species of Hyphodontia sensu lato at the family level, including the most important monograph "Die Gattung Hyphodontia John Eriksson" [14]. Hyphodontia s.l. could be split into 13 genera, of which the most species-rich ones are Xylodon and Kneiffiella P. Karst. However, due to a lack of rDNA sequences for many taxa, the molecular grounds were not enough to define separate genera clearly. Therefore the mycologists adopted a broad concept of Hyphodontia s.1. [25]. Molecular phylogeny analyses were performed by maximum parsimony and Bayesian methods, in which the phylograms from both analyses confirmed that the taxa from genera of Xylodon, Schizopora, Palifer Stalpers \& P.K. Buchanan, Lyomyces P. Karst. and Rogersella Liberta \& A.J. Navas were mixed within Xylodon-Lyomyces-Rogersella clade and Xylodon-Schizopora-Palifer clade [34]. Based on the morphological and/or phylogenetic information on Hyphodontia s.l., it was hard to differentiate between the genera Xylodon and Schizopora, with neither morphological nor molecular data and proposed that both genera should be united in one genus [22]. Used sequences from the ITS and nuclear LSU regions to infer the phylogenetic position of the Xylodon, confirmed Lagarobasidium Jülich as a synonym of Xylodon, in which three species X. magnificus (Gresl. \& Rajchenb.) K.H. Larss., X. pumilius (Gresl. \& Rajchenb.) K.H. Larss., and X. rickii (Gresl. \& Rajchenb.) K.H. Larss. were transferred into Xylodon from Lagarobasidium [27]. Phylogenetic analyses of ITS and 28S sequences revealed that Palifer and Odontiopsis Hjortstam \& Ryvarden should be synonymized under Xylodon and proposed four species new to science as X. exilis Yurchenko, Riebesehl \& Langer, X. filicinus Yurchenko \& Riebesehl, X. follis Riebesehl, Yurchenko \& Langer, and X. pseudolanatus Nakasone, Yurchenko \& Riebesehl [31]. The comprehensive phylogenetic analyses on the basis of multiple loci on Hyphodontia s.l. showed that the six genera were separated into four clades within Hymenochaetales, in which Fasciodontia Yurchenko \& Riebesehl, Lyomyces, and Xylodon were accepted as members of a previously known family Schizoporaceae [3]. Maximum parsimony strict consensus tree illustrating the phylogeny of Xylodon species based on ITS sequences showed that X. gossypinus C.L. Zhao \& K.Y. Luo grouped with X. brevisetus (P. Karst.) Hjortstam \& Ryvarden, and X. macrosporus C.L. Zhao \& K.Y. Luo was sister to X. follis and X. sinensis C.L. Zhao \& K.Y. Luo formed two sister groups to $X$. attenuatus Spirin \& Viner and X. yarraensis Xue W. Wang \& L.W. Zhou with very low supports [32].

During investigations on wood-decaying fungi in southern China, three additional Xylodon taxa were found, which could not be assigned to any described species. The present study examines the taxonomy and phylogeny of the three new species within Xylodon. The current study focuses on the phylogenetic and taxonomic study of Xylodon, based on the internal transcribed spacer (ITS) and the large subunit nuclear ribosomal RNA gene (nLSU) sequences.

\section{Materials and Methods}

\subsection{Sample Collection}

Fresh fruiting bodies of the fungi were collected from the Dali, Puer, Wenshan, Yuxi of Yunnan Province, P.R. China. The dried specimens were dried in an electric food dehydrator at $40{ }^{\circ} \mathrm{C}$, then sealed and stored in an envelope bag and deposited in the herbarium of the Southwest Forestry University (SWFC), Kunming, Yunnan Province, P.R. China. 


\subsection{Morphology}

Macromorphological descriptions are based on field notes and photos captured in the field and lab. Color terminology follows Petersen [35]. Micromorphological data were obtained from the dried specimens after the observation under a light microscope with a magnification $10 \times 100$ oil [17]. The following abbreviations were used: $\mathrm{KOH}=5 \%$ potassium hydroxide water solution, $\mathrm{CB}-=$ acyanophilous, IKI- $=$ both inamyloid and indextrinoid, $\mathrm{L}=$ mean spore length (arithmetic average for all spores), $\mathrm{W}=$ mean spore width (arithmetic average for all spores), $\mathrm{Q}=$ variation in the $\mathrm{L} / \mathrm{W}$ ratios between the specimens studied, and $n=\mathrm{a} / \mathrm{b}$ (number of spores (a) measured from given number (b) of specimens).

\subsection{Molecular Phylogeny}

The CTAB rapid plant genome extraction kit-DN14 (Aidlab Biotechnologies Co., Ltd., Beijing, P.R. China) was used to obtain genomic DNA from the dried specimens using the manufacturer's instructions. The nuclear ribosomal ITS region was amplified with primers ITS5 and ITS4 [36]. The nuclear nLSU region was amplified with primer pair LR0R and LR7 (http:/ /lutzonilab.org/nuclear-ribosomal-dna/, accessed on 5 November 2021). The PCR procedure for ITS was as follows: initial denaturation at $95{ }^{\circ} \mathrm{C}$ for $3 \mathrm{~min}$, followed by 35 cycles at $94{ }^{\circ} \mathrm{C}$ for $40 \mathrm{~s}, 58^{\circ} \mathrm{C}$ for $45 \mathrm{~s}$ and $72{ }^{\circ} \mathrm{C}$ for $1 \mathrm{~min}$, and a final extension of $72{ }^{\circ} \mathrm{C}$ for $10 \mathrm{~min}$. The PCR procedure for nLSU was as follows: initial denaturation at $94{ }^{\circ} \mathrm{C}$ for $1 \mathrm{~min}$, followed by 35 cycles at $94{ }^{\circ} \mathrm{C}$ for $30 \mathrm{~s}, 48{ }^{\circ} \mathrm{C}$ for $1 \mathrm{~min}$ and $72{ }^{\circ} \mathrm{C}$ for $1.5 \mathrm{~min}$, and a final extension of $72{ }^{\circ} \mathrm{C}$ for $10 \mathrm{~min}$. The PCR products were purified and sequenced at Kunming Tsingke Biological Technology Limited Company (Yunnan Province, P.R. China). All newly generated sequences were deposited in NCBI GenBank (https://www.ncbi.nlm.nih.gov/genbank/, accessed on 20 October 2021) (Table 1).

Table 1. List of species, specimens, and GenBank accession numbers of sequences used in this study.

\begin{tabular}{|c|c|c|c|c|c|}
\hline \multirow{2}{*}{ Species Name } & \multirow{2}{*}{ Specimen No. } & \multicolumn{2}{|c|}{ GenBank Accession No. } & \multirow{2}{*}{ References } & \multirow{2}{*}{ Country } \\
\hline & & ITS & nLSU & & \\
\hline Fasciodontia brasiliensis & MSK-F 7245a & MK575201 & MK598734 & [37] & Brazil \\
\hline F. bugellensis & KAS-FD 10705a & MK575203 & MK598735 & [37] & France \\
\hline Hastodontia halonata & HНB-17058 & MK575207 & MK598738 & [37] & Mexico \\
\hline Hymenochaete cinnamomea & He 2074 & KU975460 & KU975500 & Unpublished & China \\
\hline Hym. rubiginosa & He 1049 & JQ716407 & JQ279667 & {$[38]$} & China \\
\hline Hyphodontia alutaria & GEL3183 & DQ340318 & DQ340373 & Unpublished & Germany \\
\hline Hyp. arguta & KHL11938 & EU118632 & EU118633 & [39] & Sweden \\
\hline Hyp. pallidula & KAS-GEL2097 & DQ340317 & DQ340372 & Unpublished & Germany \\
\hline Hyp. densispora & LWZ20170908-5 & MT319426 & МТ319160 & [3] & China \\
\hline Hyp. zhixiangii & LWZ20180903-5 & МТ319423 & MT319158 & [3] & China \\
\hline Kneiffiella barba-jovis & KHL 11730 & DQ873609 & DQ873610 & {$[31]$} & Sweden \\
\hline K. eucalypticola & LWZ20180515-9 & MT319411 & МТ319143 & [3] & Australia \\
\hline K. palmae & KAS-GEL 3456 & DQ340333 & DQ340369 & [37] & China \\
\hline K. subalutacea & GEL2196 & DQ340341 & DQ340362 & [37] & Norway \\
\hline Lyomyces allantosporus & FR 0249548 & KY800397 & KY795963 & [40] & Réunion \\
\hline L. bambusinus & CLZhao 4831 & MN945968 & MW264919 & {$[41]$} & China \\
\hline L. fimbriatus & Wu 911204-4 & MK575210 & MK598740 & [37] & China \\
\hline L. mascarensis & KAS-GEL 4833 & KY800399 & KY795964 & [37] & Réunion \\
\hline L. orientalis & LWZ20170909-7 & MT319436 & МТ319170 & [3] & China \\
\hline L. sambuci & KAS-JR 7 & KY800402 & KY795966 & {$[40]$} & Germany \\
\hline Xylodon acystidiatus & LWZ20180514-9 & МТ319474 & МТ319211 & [3] & Australia \\
\hline
\end{tabular}


Table 1. Cont.

\begin{tabular}{|c|c|c|c|c|c|}
\hline \multirow{2}{*}{ Species Name } & \multirow{2}{*}{ Specimen No. } & \multicolumn{2}{|c|}{ GenBank Accession No. } & \multirow{2}{*}{ References } & \multirow{2}{*}{ Country } \\
\hline & & ITS & nLSU & & \\
\hline X. apacheriensis & Wu 0910-58 & KX857797 & KX857822 & [42] & China \\
\hline X. asper & KHL8530 & AY463427 & AY586675 & [43] & Sweden \\
\hline X. astrocystidiatus & Wu 9211-71 & JN129972 & JN129973 & [16] & China \\
\hline X. attenuatus & Spirin 8775 & МH324476 & & [27] & USA \\
\hline X. australis & LWZ20180509-8 & МТ319503 & & [3] & China \\
\hline X. bambusinus & CLZhao 9174 & MW394657 & MW394650 & [44] & China \\
\hline X. borealis & JS26064 & AY463429 & AY586677 & [43] & Norway \\
\hline X. brevisetus & JS17863 & AY463428 & AY586676 & [43] & Norway \\
\hline X. crystalliger & LWZ20170816-33 & МT319521 & МТ319269 & [3] & China \\
\hline X. cystidiatus & FR-0249200 & MH880195 & MH884896 & [31] & Réunion \\
\hline X. damansaraensis & LWZ20180417-23 & МТ319499 & & [3] & Malaysia \\
\hline X. detriticus & Zíbarová 30.10.17 & МH320793 & MH651372 & [27] & Czech Republic \\
\hline X. filicinus & MSK F 12869 & MH880199 & NG067836 & [31] & China \\
\hline$X$. flaviporus & FR-0249797 & MH880201 & MH884901 & [31] & Réunion \\
\hline X. follis & FR-0249814 & MH880204 & MH884902 & [31] & Réunion \\
\hline X. gossypinus & CLZhao 4465 & MZ663803 & MZ663812 & [32] & China \\
\hline X. hastifer & $\mathrm{K}(\mathrm{M}) 172400$ & NR166558 & & [22] & USA \\
\hline X. heterocystidiatus & LWZ20180921-19 & МТ319676 & MT319266 & [3] & Australia \\
\hline X. heterocystidiatus & Wei 17-314 & MT731753 & MT731754 & Unpublished & China \\
\hline X. hyphodontinus & KAS-GEL9222 & MH880205 & MH884903 & [31] & Kenya \\
\hline X. kunmingensis & TUB-FO 42565 & MH880198 & MH884898 & [31] & China \\
\hline X. laceratus & CLZhao 9841 & OL619257 & OL619265 & Present study & China \\
\hline X. laceratus & CLZhao 9892 [T] & OL619258 & OL619266 & Present study & China \\
\hline X. lagenicystidiatus & LWZ20180513-16 & МТ319634 & МТ319368 & [3] & Australia \\
\hline X. lenis & Wu890714-3 & KY081802 & & [22] & China \\
\hline X. macrosporus & CLZhao 10226 & MZ663809 & MZ663817 & [32] & China \\
\hline X. mollissimus & LWZ20160318-3 & KY007517 & МT319347 & [3] & China \\
\hline X. montanus & CLZhao 8118 & OL619259 & OL619267 & Present study & China \\
\hline X. montanus & CLZhao 8179 [T] & OL619260 & OL619268 & Present study & China \\
\hline X. nesporii & LWZ20180921-35 & МT319655 & МT319238 & [3] & China \\
\hline X. niemelaei & LWZ20150707-13 & МT319630 & МT319365 & [3] & China \\
\hline$X$. nongravis & GC1412-22 & KX857801 & KX857818 & [42] & China \\
\hline X. nothofagi & ICMP 13842 & AF145583 & & [45] & China \\
\hline X. ovisporus & LWZ20170815-31 & МТ319666 & MT319346 & [3] & China \\
\hline X. papillosus & CBS 114.71 & MH860026 & & [46] & Netherlands \\
\hline X. paradoxus & Dai14983 & МТ319519 & МТ319267 & [3] & China \\
\hline X. pruinosus & Spirin 2877 & МН332700 & & [27] & Estonia \\
\hline X. pseudolanatus & FP-150922 & MH880220 & NG067837 & {$[31]$} & Belize \\
\hline X. pseudotropicus & Dai16167 & MT319509 & MT319255 & [3] & China \\
\hline X. quercinus & KHL11076 & КT361633 & AY586678 & [43] & Sweden \\
\hline X. ramicida & Spirin 7664 & NR138013 & & Unpublished & USA \\
\hline X. rhododendricola & LWZ20180513-9 & MT319621 & MT319357 & [3] & Australia \\
\hline X. rimosissimus & Ryberg 021031 & DQ873627 & DQ873628 & [47] & Sweden \\
\hline X. serpentiformis & LWZ20170816-15 & МT319673 & MT319218 & [3] & China \\
\hline X. sinensis & CLZhao 9197 & MZ663810 & MZ663818 & [32] & China \\
\hline X. spathulatus & LWZ20180804-10 & МТ319646 & MT319354 & [3] & China \\
\hline X. subclavatus & TUB-FO 42167 & MH880232 & & [31] & China \\
\hline X. subflaviporus & Wu 0809-76 & KX857803 & KX857815 & {$[42]$} & China \\
\hline X. subserpentiformis & LWZ20180512-16 & МТ319486 & MT319226 & [3] & Australia \\
\hline X. subtropicus & LWZ20180510-24 & MT319541 & MT319308 & [3] & China \\
\hline X. taiwanianus & CBS 125875 & MH864080 & MH875537 & [46] & Netherlands \\
\hline
\end{tabular}


Table 1. Cont.

\begin{tabular}{|c|c|c|c|c|c|}
\hline \multirow{2}{*}{ Species Name } & \multirow{2}{*}{ Specimen No. } & \multicolumn{2}{|c|}{ GenBank Accession No. } & \multirow{2}{*}{ References } & \multirow{2}{*}{ Country } \\
\hline & & ITS & nLSU & & \\
\hline X. tropicus & CLZhao 3351 [T] & OL619261 & OL619269 & Present study & China \\
\hline X. tropicus & CLZhao 3355 & OL619262 & & Present study & China \\
\hline X. tropicus & CLZhao 3395 & OL619263 & OL619270 & Present study & China \\
\hline X. tropicus & CLZhao 3397 & OL619264 & OL619271 & Present study & China \\
\hline X. ussuriensis & KUN 1989 & NR166241 & & Unpublished & USA \\
\hline X. verecundus & KHL 12261 & DQ873642 & DQ873643 & [47] & Sweden \\
\hline X. victoriensis & LWZ20180510-29 & МТ319487 & МТ319228 & [3] & Australia \\
\hline X. xinpingensis & CLZhao 11224 & MW394662 & MW394654 & [44] & China \\
\hline$X$. yarraensis & LWZ20180510-5 & МТ319639 & МТ319378 & [3] & Australia \\
\hline X. yunnanensis & LWZ20180922-47 & МТ319660 & & [3] & China \\
\hline
\end{tabular}

[T] is shown type material, holotype.

The sequences were aligned in MAFFT 7 (https://mafft.cbrc.jp/alignment/server/, accessed on 5 November 2021) using the "G-INS-i" strategy for the ITS and ITS+nLSU dataset. The alignment was adjusted manually using BioEdit [48]. The dataset was aligned first, and then ITS and nLSU sequences were combined with Mesquite version 3.51. Alignment datasets were deposited in TreeBASE (submission ID 29060). ITS + nLSU sequences and ITS-only datasets were used to infer the position of the three new species among Xylodon and related taxa. Sequences of Hymenochaete cinnamomea (Pers.) Bres. and H. rubiginosa (Dicks.) Lév. retrieved from GenBank were used as an outgroup in the ITS+nLSU analysis (Figure 1); sequences of Lyomyces mascarensis Riebesehl, Yurchenko \& Langer, and L. sambuca (Pers.) P. Karst. retrieved from GenBank were used as an outgroup in the ITS-only analysis (Figure 2) [3].

Maximum parsimony (MP), maximum likelihood (ML), and Bayesian inference (BI) analyses were applied to the combined three datasets following a previous study [49], and the tree construction procedure was performed in PAUP* version 4.0b10 [50]. All characters were equally weighted, and gaps were treated as missing data. Using the heuristic search option with TBR branch swapping and 1000 random sequence additions, trees were inferred. Max-trees were set to 5000, branches of zero length were collapsed, and all parsimonious trees were saved. Clade robustness was assessed using bootstrap (BT) analysis with 1000 replicates [51]. Descriptive tree statistics-tree length (TL), consistency index $(\mathrm{CI})$, retention index (RI), rescaled consistency index (RC), and homoplasy index (HI)were calculated for each maximum parsimonious tree generated. The multiple sequence alignment was also analyzed using maximum likelihood (ML) in RAxML-HPC2 through the Cipres Science Gateway [52]. Branch support (BS) for ML analysis was determined by 1000 bootstrap replicates.

MrModeltest 2.3 [53] was used to determine the best-fit evolution model for each data set for Bayesian inference (BI), which was performed using MrBayes 3.2.7a with a GTR + I + G model of DNA substitution and a gamma distribution rate variation across sites [54]. A total of 4 Markov chains were run for 2 runs from random starting trees for 6 million generations for ITS + nLSU (Figure 1) and 7.5 million generations for ITS (Figure 2) with trees and parameters sampled every 1000 generations. The first one-fourth of all generations were discarded as burn-in. The majority-rule consensus tree of all remaining trees was calculated. Branches were considered as significantly supported if they received maximum likelihood bootstrap value (BS) $>70 \%$, maximum parsimony bootstrap value (BT) $>70 \%$, or Bayesian posterior probabilities (BPP) $>0.95$. 


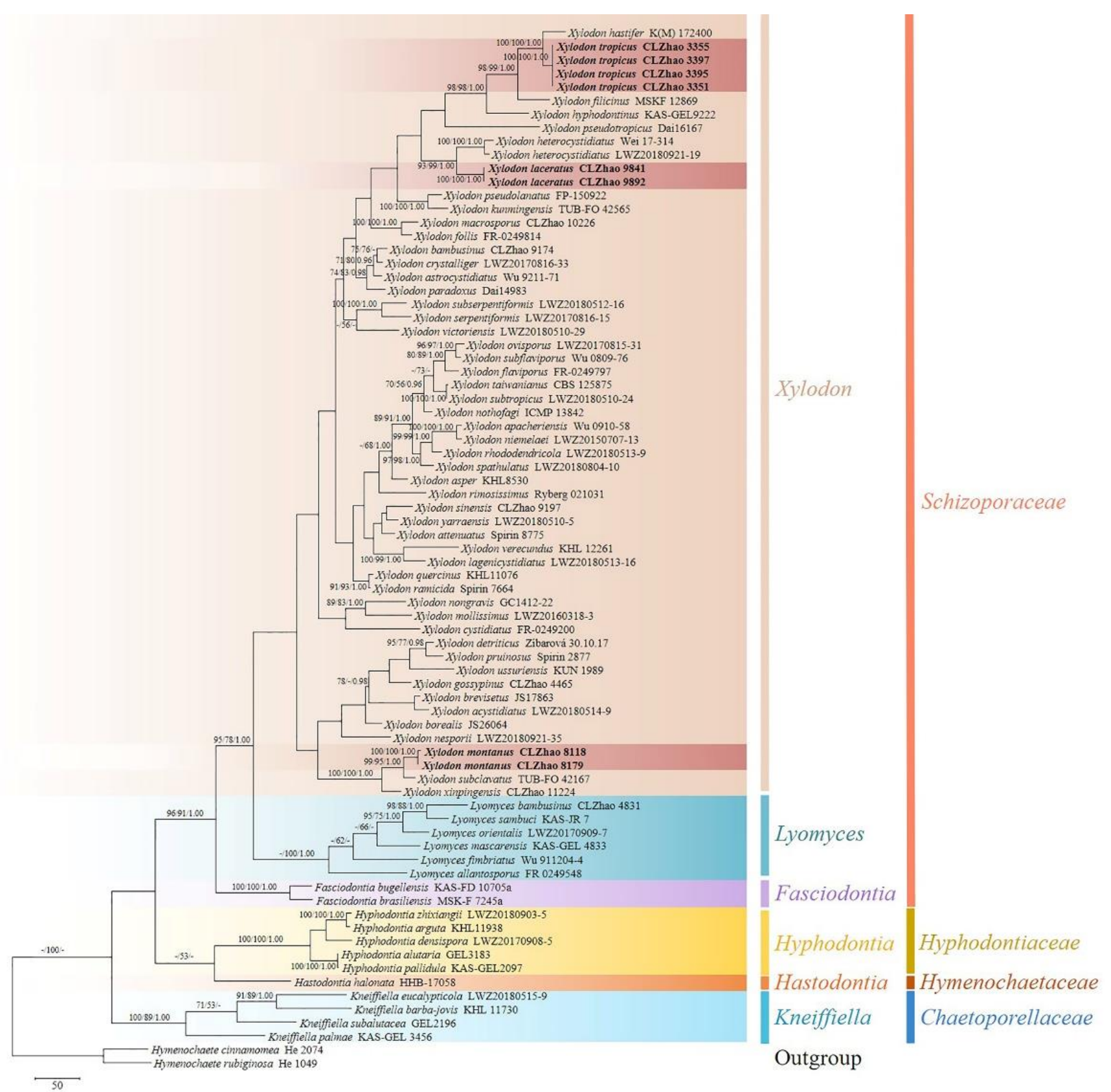

Figure 1. Maximum parsimony strict consensus tree illustrating the phylogeny of Xylodon and related genera in Hymenochaetales based on ITS + nLSU sequences. 

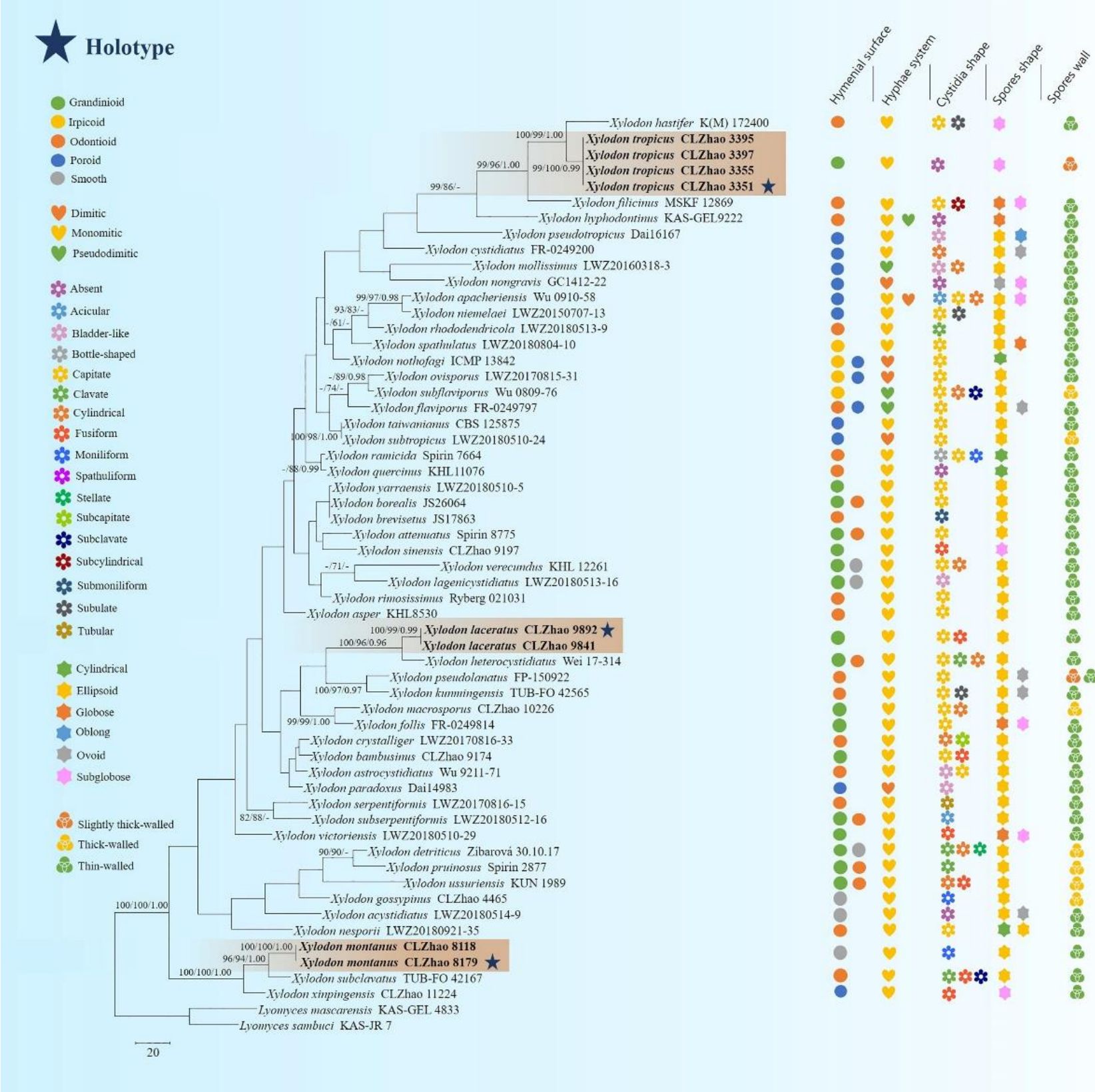

Figure 2. Maximum parsimony strict consensus tree illustrating the phylogeny of three new species in Xylodon based on ITS sequences. Branches are labeled with maximum likelihood bootstrap value $>70 \%$, parsimony bootstrap value $>50 \%$, and Bayesian posterior probabilities $>0.95$, respectively. The new species are in bold.

\section{Results}

\subsection{Molecular Phylogeny}

The ITS+nLSU dataset (Figure 1) included sequences from 77 fungal specimens representing 71 species. The dataset had an aligned length of 2269 characters. Maximum parsimony analysis yielded 26 equally parsimonious trees $(\mathrm{TL}=4541, \mathrm{CI}=0.3510, \mathrm{HI}=0.6490, \mathrm{RI}=$ 0.5827 , and $R C=0.2045)$. The best model for the ITS + nLSU dataset estimated and applied in the Bayesian analysis was GTR + I + G. Bayesian analysis and ML analysis resulted in a similar topology to MP analysis with an average standard deviation of split frequencies = 0.015456 (BI), and the effective sample size (ESS) average ESS (avg ESS) = 791. The phylogram based on the ITS+nLSU rDNA gene regions (Figure 1), including the six genera, Fasciodon- 
tia, Hastodontia (Parmasto) Hjortstam \& Ryvarden, Hyphodontia, Kneiffiella, Lyomyces, and Xylodon, were divided into four families within Hymenochaetales, which showed that three genera Fasciodontia, Lyomyces, and Xylodon nested into the family Schizoporaceae. Our current three new species clustered into the family Schizoporaceae separated into genus Xylodon. Xylodon laceratus was a sister to X. heterocystidiatus (H.X. Xiong, Y.C. Dai \& Sheng H. Wu) Riebesehl, Yurchenko \& Langer; X. montanus closely related with X. subclavatus (H.X. Xiong, Y.C. Dai \& Sheng H. Wu) Riebesehl, Yurchenko \& Langer and X. xinpingensis C.L. Zhao \& X. Ma with high supports; X. tropicus was retrieved as a sister to X. hastifer (Hjortstam \& Ryvarden) Hjortstam \& Ryvarden.

The ITS-alone dataset (Figure 2) included sequences from 58 fungal specimens representing 53 species. The dataset had an aligned length of 875 characters. Maximum parsimony analysis yielded 5000 equally parsimonious trees $(\mathrm{TL}=2054, \mathrm{CI}=0.2965$, $\mathrm{HI}=0.7035$, $\mathrm{RI}=0.4580$, and $\mathrm{RC}=0.1358)$. The best model for the ITS dataset estimated and applied in the Bayesian analysis was GTR+I+G. Bayesian analysis and ML analysis resulted in a similar topology to the MP analysis with an average standard deviation of split frequencies $=0.028998(\mathrm{BI})$, and the effective sample size (ESS) of the average ESS $(\operatorname{avg} \mathrm{ESS})=574$.

\subsection{Taxonomy}

Xylodon laceratus C.L. Zhao, sp. nov. Figures 3 and 4.

MycoBank no.: 842068

Holotype-China. Yunnan Province, Puer, Jingdong County, Wuliangshan National Nature Reserve, GPS $22^{\circ} 46^{\prime} \mathrm{N}, 100^{\circ} 58^{\prime}$ E, altitude $1400 \mathrm{~m}$ asl., on the trunk of angiosperm with bark, within the broad-leaved forest, leg. C.L. Zhao, 6 October 2017, CLZhao 9892 (SWFC).

Etymology-laceratus (Lat.): referring to the cracked hymenophore of the specimens.

Fruiting body-Basidiomata annual, resupinate, soft, without odor and taste when fresh, becoming coriaceous when fresh, hard coriaceous upon drying, up to $20 \mathrm{~cm}$ long, $3 \mathrm{~cm}$ wide, 50-110 $\mu \mathrm{m}$ thick. Hymenial surface grandinioid, aculei up to $0.1 \mathrm{~mm}$ long, cream when fresh, cream to buff upon drying, cracking. Sterile margin indistinct, cream, 0.5-1 mm wide, unattached.

Hyphal system-Monomitic, generative hyphae with clamps, colorless, thin-walled, frequently branched, interwoven, 1.8-4.4 $\mu \mathrm{m}$ in diameter, hyphae tight in aculei, IKI-, $\mathrm{CB}-$; tissues unchanged in $\mathrm{KOH}$; subhymenial hyphae densely covered by larger, irregular crystals; a basal layer of hyphae parallel.

Hymenium-Cystidia of two types: (1) capitate cystidia rare, smooth, colorless, thinwalled, slightly constricted at the neck, with a globose head, 15.4-24.7 $\times 3.8-4.7 \mu \mathrm{m}$; (2) fusiform cystidia frequently, smooth, colorless, thin-walled, 20.3-26.8 × 5.3-6.4 $\mu \mathrm{m}$; basidia barreled to clavate, with four sterigmata and a basal clamp connection, 11-17.5 $\times 3.2-5.5 \mu \mathrm{m}$.

Spores-Basidiospores ellipsoid, colorless, thin-walled, smooth, with one oil drop inside, IKI-, CB-, (3.7-)3.9-5.3 × 2.6-4.1(-4.8) $\mu \mathrm{m}, \mathrm{L}=4.52 \mu \mathrm{m}, \mathrm{W}=3.35 \mu \mathrm{m}, \mathrm{Q}=1.28-1.43$ $(n=60 / 2)$

Additional specimen examined-China, Yunnan Province, Puer, Jingdong County, Wuliangshan National Nature Reserve, GPS $22^{\circ} 46^{\prime} \mathrm{N}, 100^{\circ} 58^{\prime}$ E, altitude $1400 \mathrm{~m}$ asl., on the trunk of angiosperm with bark, within the broad-leaved forest, leg. C.L. Zhao, 6 October 2017, CLZhao 9841 (SWFC).

Xylodon montanus C.L. Zhao, sp. nov. Figures 5 and 6. 

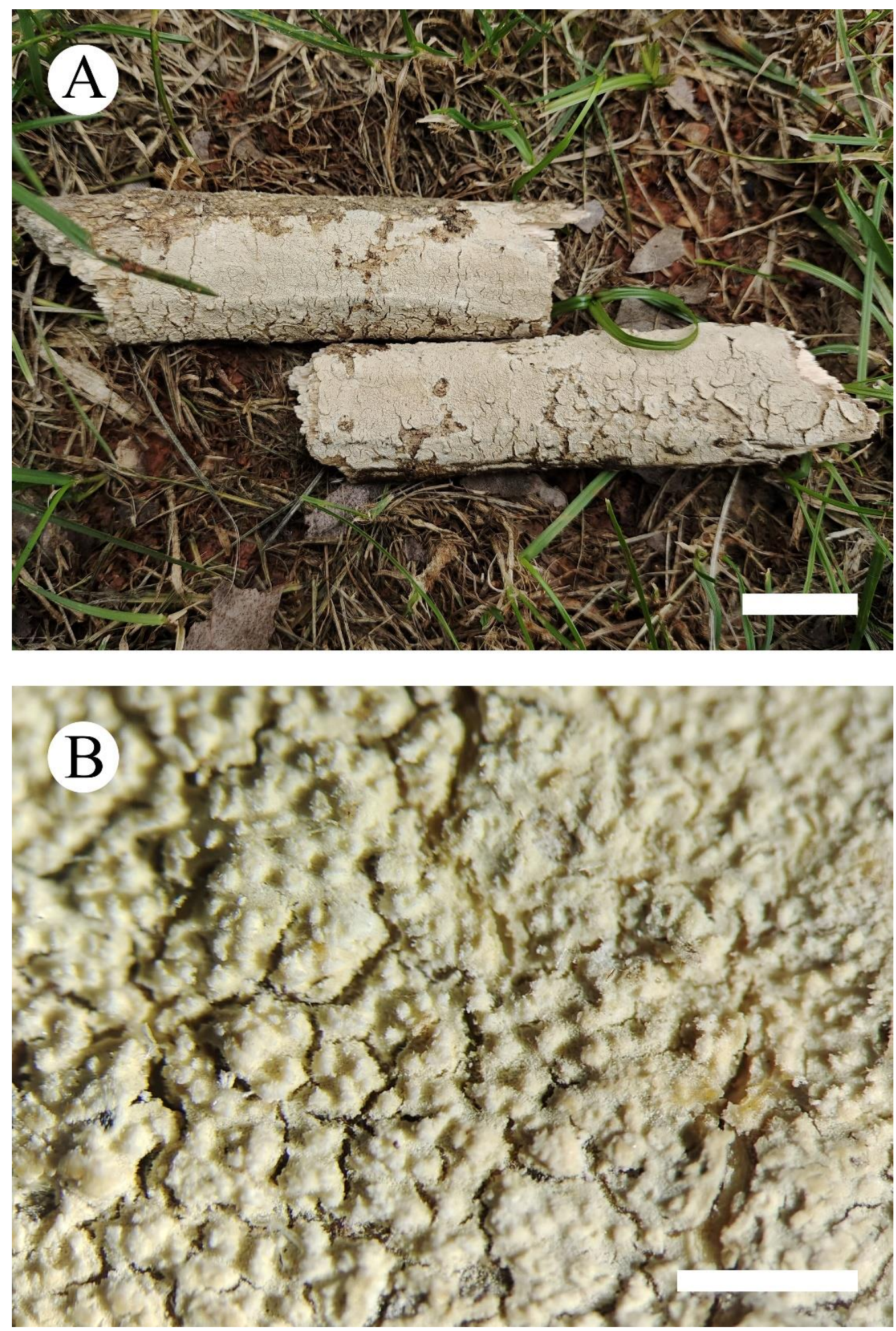

Figure 3. Basidiomata of Xylodon laceratus (holotype): the front of the basidiomata (A), character hymenophore (B). Bars: $(\mathbf{A})=2 \mathrm{~cm}$ and $(\mathbf{B})=1 \mathrm{~mm}$. 

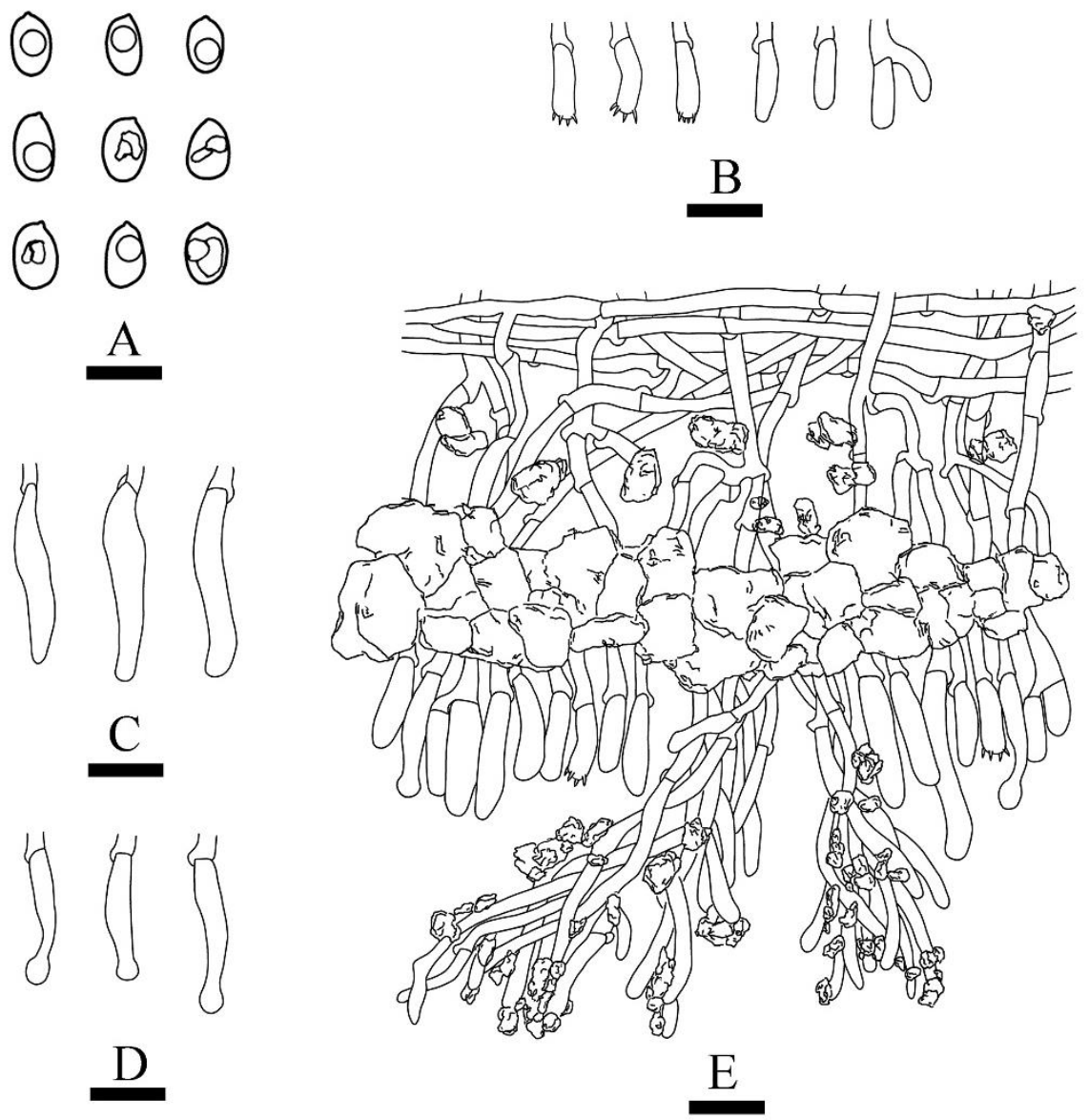

Figure 4. Microscopic structures of Xylodon laceratus (holotype): basidiospores (A), basidia and basidioles (B), fusiform cystidia (C), capitate cystidia (D), A section of hymenium (E). Bars: (A) $=5$ $\mu \mathrm{m},(\mathbf{B})-(\mathrm{E})=10 \mu \mathrm{m}$.

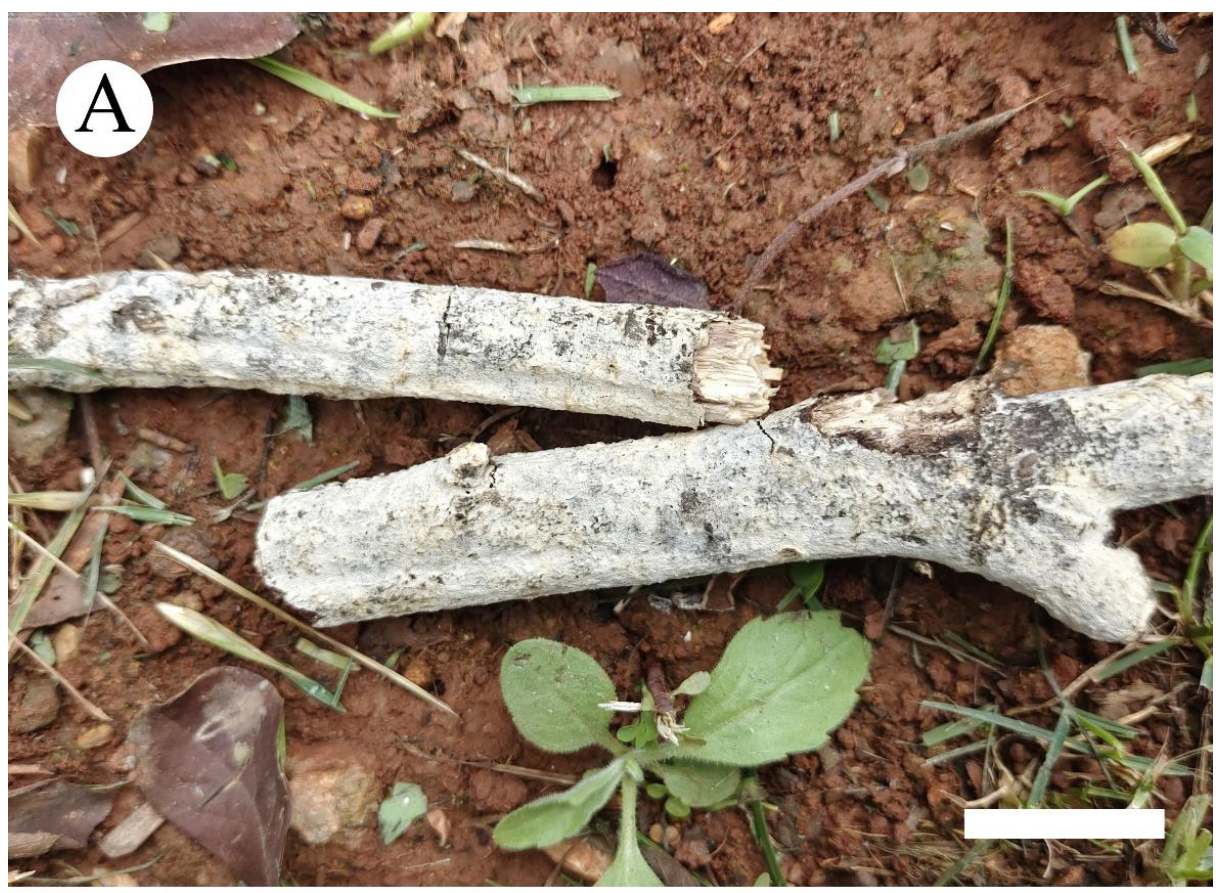

Figure 5. Cont. 


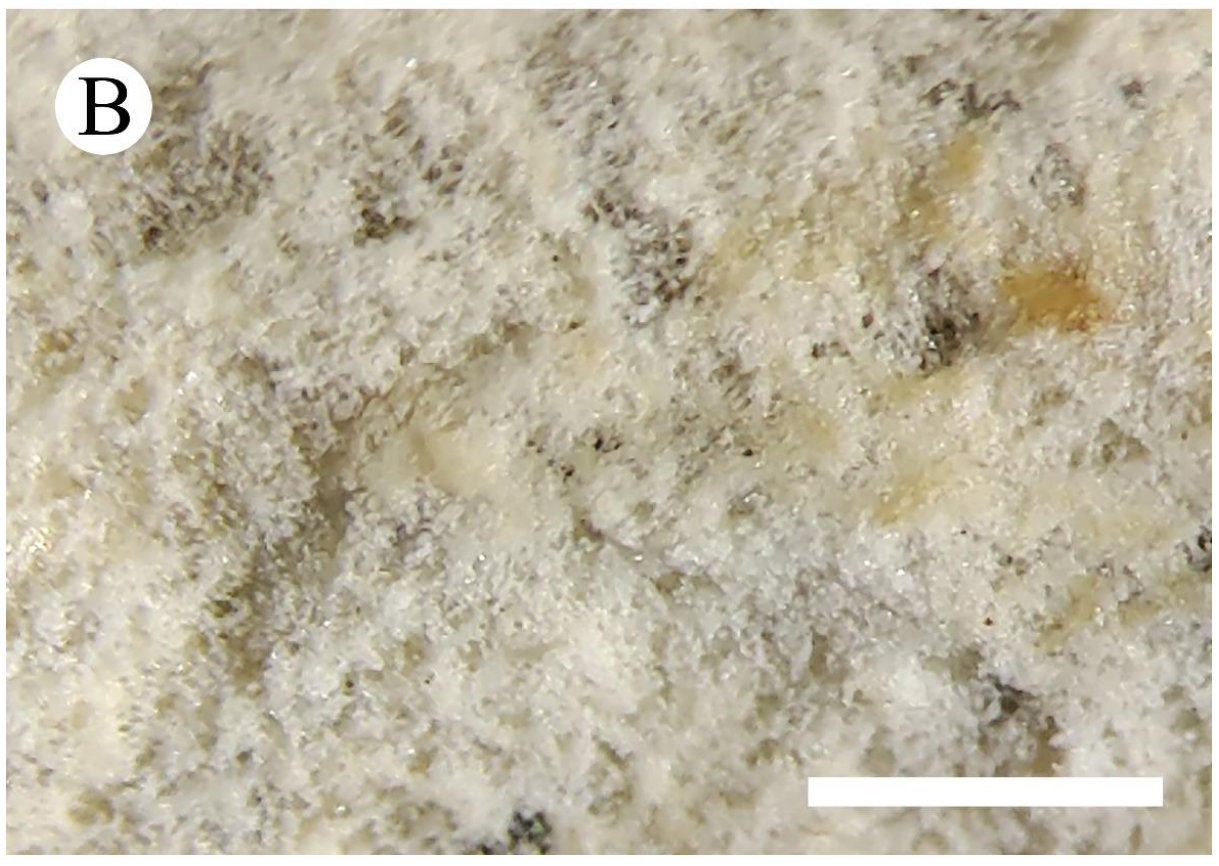

Figure 5. Basidiomata of Xylodon montanus (holotype): the front of the basidiomata (A), character hymenophore (B). Bars: $(\mathbf{A})=2 \mathrm{~cm}$ and $(\mathbf{B})=0.5 \mathrm{~mm}$.
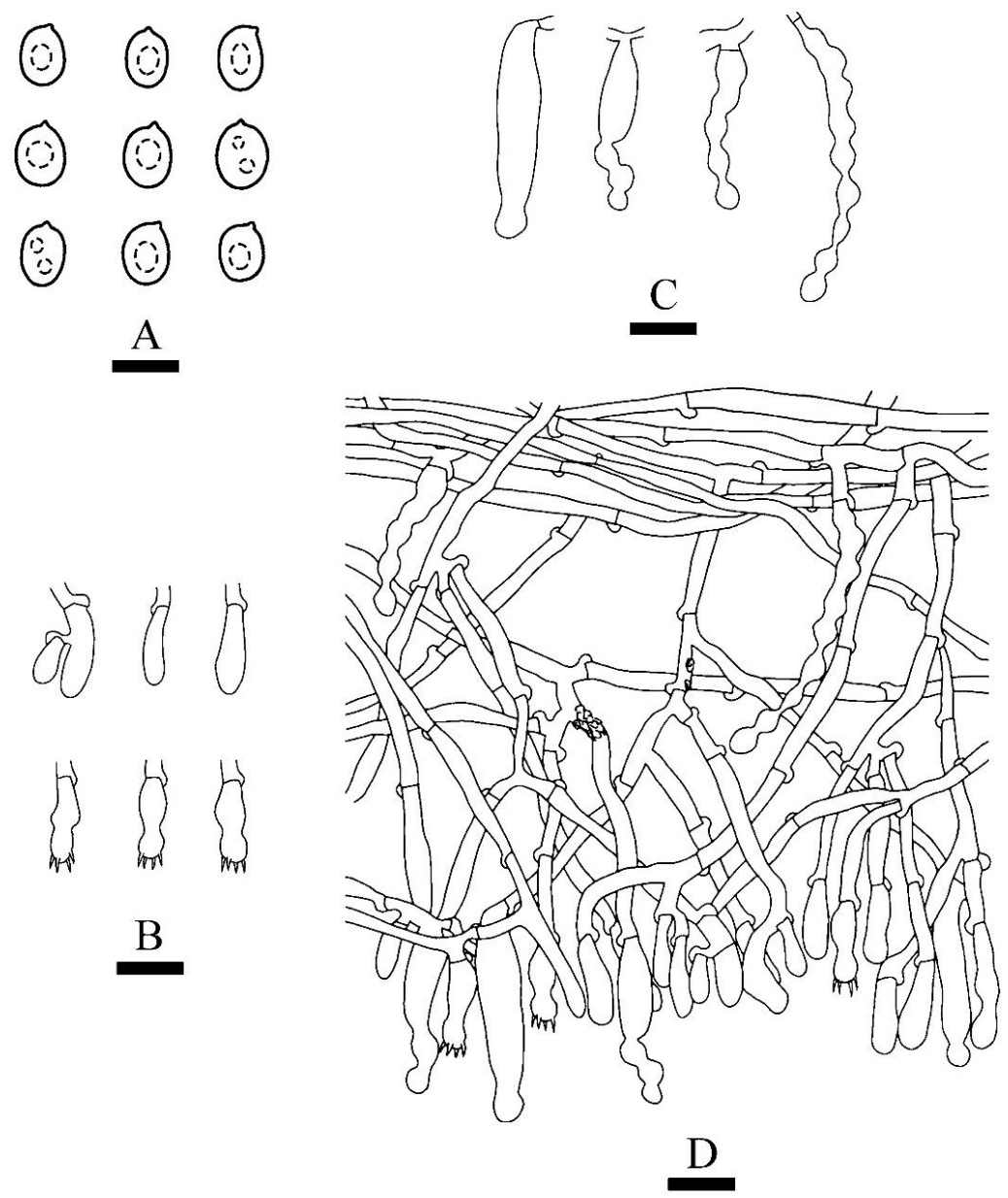

Figure 6. Microscopic structures of Xylodon montanus (holotype): basidiospores (A), basidia and basidioles (B), moniliform cystidia (C), A section of hymenium (D). Bars: (A) $=5 \mu \mathrm{m},(\mathbf{B}-\mathbf{D})=10 \mu \mathrm{m}$. 
MycoBank no.: 842069

Holotype-China. Yunnan Province, Yuxi, Xinping County, Chama Ancient Road Scenic spot, GPS $23^{\circ} 96^{\prime} \mathrm{N}, 101^{\circ} 51^{\prime} \mathrm{E}$, altitude $2183 \mathrm{~m}$ asl., on the angiosperm fallen branch with bark, within the mixed broadleaf-conifer forest, leg. C.L. Zhao, 21 August 2018, CLZhao 8179 (SWFC).

Etymology-montanus (Lat.): referring for species collected in montane habitat in Yunnan-Guizhou Plateau.

Fruiting body-Basidiomata annual, resupinate, woolly when fresh, hard brittle when dry, up to $15 \mathrm{~cm}$ long, $3.5 \mathrm{~cm}$ wide, $80-130 \mu \mathrm{m}$ thick. Hymenial surface smooth, white to cream when fresh, cream upon drying. Sterile margin indistinct, white to cream, about $1 \mathrm{~mm}$ wide, attached.

Hyphal system-Monomitic, generative hyphae with clamps, colorless, thin-walled, frequently branched, interwoven, 1.3-3.7 $\mu \mathrm{m}$ in diameter, IKI-, CB-; tissues unchanged in $\mathrm{KOH}$; a basal layer of hyphae parallel.

Hymenium-Cystidia moniliform, numerous, smooth, colorless, thin-walled, slightly constricted at the neck, with a globose head, 19.5-47.6 $\times 3.6-7.1 \mu \mathrm{m}$, rare presence of one globose head; basidia subclavate to clavate with a median constriction, with four sterigmata and a basal clamp connection, 10.1-17.8 $\times 3.8-5.6 \mu \mathrm{m}$.

Spores-Basidiospores ellipsoid to broad ellipsoid, colorless, thin-walled, smooth, IKI-, CB-, 3.9-5.3 × 3.2-4.3 $\mu \mathrm{m}, \mathrm{L}=4.68 \mu \mathrm{m}, \mathrm{W}=3.61 \mu \mathrm{m}, \mathrm{Q}=1.27-1.32(n=60 / 2)$.

Additional specimen examined-China, Yunnan Province, Puer, Zhenyuan County, Ailaoshan, Jinshan Original Forestry, GPS $23^{\circ} 94^{\prime} \mathrm{N}, 101^{\circ} 52^{\prime} \mathrm{E}$, altitude $2310 \mathrm{~m}$ asl., on the angiosperm fallen branch with bark, mixed broadleaf-conifer forest, leg. C.L. Zhao, 21 August 2018, CLZhao 8118 (SWFC).

Xylodon tropicus C.L. Zhao, sp. nov. Figures 7 and 8.

MycoBank no.: 842070

Holotype-China. Yunnan Province, Puer, Zhenyuan County, Xieqipo Park, GPS $24^{\circ} 01^{\prime} \mathrm{N}, 101^{\circ} 10^{\prime} \mathrm{E}$, altitude $1121 \mathrm{~m}$ asl., on the branch of dead bamboo, in the bamboo forest, leg. C.L. Zhao, 1 October 2017, CLZhao 3351 (SWFC).

Etymology-tropicus (Lat.): referring to distribution (tropical zone) of the new species.

Fruiting body-Basidiomata annual, resupinate, adnate, coriaceous, without odor and taste when fresh, up to $15 \mathrm{~cm}$ long, $6.5 \mathrm{~cm}$ wide, 110-250 $\mu \mathrm{m}$ thick. Hymenial surface grandinioid, cream when fresh, buff to pale brown on drying. Sterile margin indistinct, cream to buff, about $1 \mathrm{~mm}$ wide, unattached.

Hyphal system-Monomitic, generative hyphae with clamps, colorless, thick-walled, 0.4-0.75 $\mu \mathrm{m}$ thick, frequently branched, interwoven, 2.2-3.7 $\mu \mathrm{m}$ in diameter; IKI-, CB-; tissues unchanged in $\mathrm{KOH}$.

Hymenium-Cystidia absent and cystidioles fusiform, rare, 7.2-15 × 2.9-4.8 $\mu \mathrm{m}$; basidia barreled, slightly constricted in the middle to somewhat sinuous, with four sterigmata and a basal clamp, 7.1-13.5 × 2.3-4 $\mu \mathrm{m}$.

Spores-Basidiospores subglobose, colorless, slightly thick-walled, 0.1-0.3 $\mu \mathrm{m}$ thick, smooth, IKI-, CB-, (1.7-)2-4.8 × 1.6-4(-4.4) $\mu \mathrm{m}, \mathrm{L}=3.55 \mu \mathrm{m}, \mathrm{W}=3.06 \mu \mathrm{m}, \mathrm{Q}=1.15-1.17$ $(n=120 / 4)$.

Additional species examined-China, Yunnan Province, Puer, Zhenyuan County, Xieqipo Park, GPS $24^{\circ} 01^{\prime} \mathrm{N}, 101^{\circ} 10^{\prime}$ E, altitude $1121 \mathrm{~m}$ asl., on the branch of dead bamboo, in the bamboo forest, leg. C.L. Zhao, 1 October 2017, CLZhao 3355, CLZhao 3395, CLZhao 3397 (SWFC). 

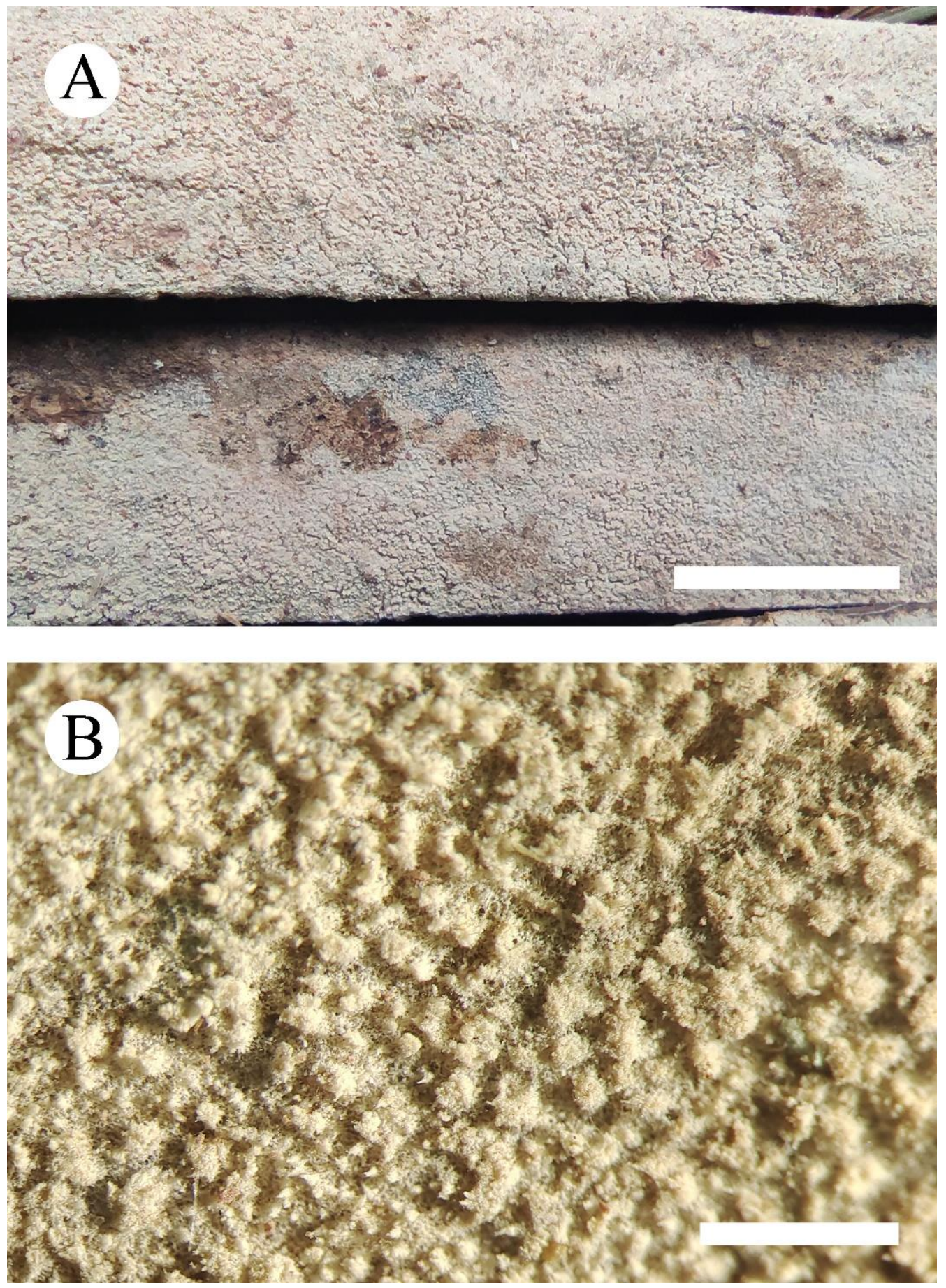

Figure 7. Basidiomata of Xylodon tropicus (holotype): the front of the basidiomata (A), character hymenophore (B). Bars: $(\mathbf{A})=1 \mathrm{~cm}$ and $(\mathbf{B})=1 \mathrm{~mm}$. 

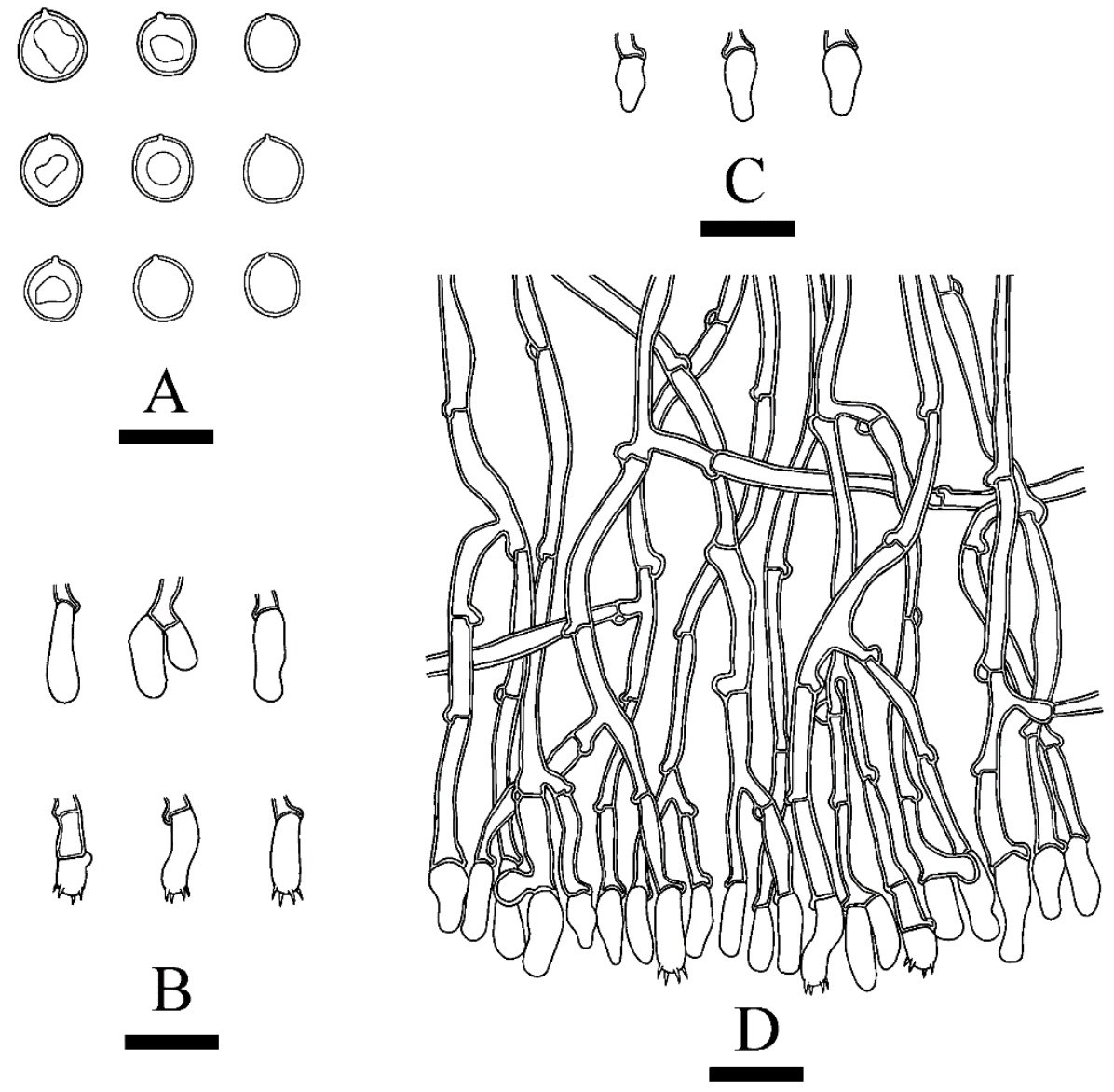

Figure 8. Microscopic structures of Xylodon tropicus (holotype): basidiospores (A), basidia and basidioles (B), and fusiform cystidioles (C), A section of hymenium (D). Bars: $(\mathbf{A})=5 \mu \mathrm{m},(\mathbf{B}-\mathbf{D})=$ $10 \mu \mathrm{m}$.

\section{Discussion}

In their geographical distribution and ecological preferences, the members of Xylodon are widespread and primarily wood decomposers, causing a white-rot of woody substrates, which are widely distributed in various forest ecosystems from boreal, temperate, subtropical, to tropical zones [16,55]. Some taxa of Xylodon have been collected on rotten trunks and stumps of conifers and angiosperms, bamboo, and ferns [3,12,32,34,44,56-72].

Phylogenetically, the molecular relationships of species belonging to Hyphodontia s.l. within Hymenochaetales inferred from the combined dataset of ITS, nLSU, and mt-SSU regions, showed that the phylogeny employed by the dataset strongly supported Hymenochaetales as an independent order, in which seven families, Chaetoporellaceae, Coltriciaceae, Hymenochaetaceae, Neoantrodiellaceae, Nigrofomitaceae, Oxyporaceae, Schizoporaceae were as seven monophyletic lineages, that several genera nested into Hyphodontia s.l. were supported as independent genera [3]. In the present study (Figure 1), four related families in the order Hymenochaetales were carried out by the ITS+nLSU analysis, which showed that the six genera, Fasciodontia, Hastodontia, Hyphodontia, Kneiffiella, Lyomyces, and Xylodon nested into related families, and our three new taxa clustered into genus Xylodon, belonging to the family Schizoporaceae.

Molecular phylogeny of the genus Xylodon based on the ITS-alone dataset included sequences from 61 fungal specimens representing 55 species, revealed that X. gossypinus, $X$. macrosporus, and X. sinensis were grouped into three different subclades of Xylodon. X. gossypinus grouped closely with X. ussuriensis Viner; X. macrosporus grouped with X. follis with high supports, and $X$. sinensis grouped to a clade comprising $X$. attenuatus and 
$X$. yarraensis with lower supports [32]. In the current study (Figure 1), our three undescribed taxa nested into the genus Xylodon, in which X. laceratus was a sister to X. heterocystidiatus; $X$. montanus closely grouped with $X$. subclavatus and X. xinpingensis with a high supports; $X$. tropicus was retrieved as a sister to X. hastifer. The ITS-based minimum evolution phylogram for Xylodon and allied species showed that X. cystidiatus (A. David \& Rajchenb.) Riebesehl \& Langer, X. hyphodontinus (Hjortstam \& Ryvarden) Riebesehl, Yurchenko \& G. Gruhn, X. serpentiformis (Langer) Hjortstam \& Ryvarden and X. subclavatus formed individual lineages in genus Xylodon, and two genera Palifer and Odontiopsis were synonymized under Xylodon based on morphological and sequence data [31]; in the same study, X. erikssonii (M. Galán \& J.E. Wright) Riebesehl \& Langer, X. gamundiae (Gresl. \& Rajchenb.) Riebesehl \& Langer, X. hjortstamii (Gresl. \& Rajchenb.) Riebesehl \& Langer, X. hyphodontinus, X. septocystidiatus (H.X. Xiong, Y.C. Dai \& Sheng H. Wu) Riebesehl \& Langer and X. verecundus (G. Cunn.) Yurchenko \& Riebesehl were proposed as the new combinations [31]. Our new taxa based on the ITS dataset analysis showed that X. tropicus and $X$. hyphodontinus grouped within the same subclade; both X. laceratus and X. serpentiformis clustered in the same subclade, but they were distinct; $X$. montanus was closely grouped with X. subclavatus with a well supports. However, morphologically, Xylodon heterocystidiatus differs from $X$. laceratus by having the membranaceous basidiomata and cylindrical or clavate leptocystidia $(34-51 \times 6-9 \mu \mathrm{m})$ [11]. X. subclavatus is different than $X$. montanus by having the cracked basidiomata, odontioid hymenial surface, and subclavate, cylindrical or fusiform cystidia $(12-33 \times 4.5-8.5 \mu \mathrm{m})$ [15]. X. xinpingensis is different from $X$. montanus by having the reticulate hymenophore, fusiform cystidia $(19.5-31 \times 2-6 \mu \mathrm{m})$, bigger basidia $(18.5-33 \times 3-6.5 \mu \mathrm{m})$, and subglobose basidiospores $(4.5-6 \times 3.5-5 \mu \mathrm{m})$ [44]. X. hastifer could be delimited from $X$. tropicus by its whitish, distinctly odontioid hymenophore, and subulate cystidia $(40-60 \times 6-8 \mu \mathrm{m})$ [25].

Morphologically, Xylodon laceratus is similar to X. australis (Berk.) Hjortstam \& Ryvarden, $X$, gamundiae, X. macrosporus, X. rhododendricola Xue W. Wang \& L.W. Zhou and X. subserpentiformis Xue W. Wang \& L.W. Zhou by the cracked hymenophore. However, Xylodon australis is diverse from $X$. laceratus by its membranous basidiomata with a brown hymenial surface with an olive tint and subulate, sinuous, or moniliform cystidia $(40-60 \times 10-20 \mu \mathrm{m})$ [22]; X. gamundiae is different than $X$. laceratus by its suburniform to sinuous basidia $(20-30 \times 4-5 \mu \mathrm{m})$ and cylindrical to subcylindrical basidiospores $(6-6.5 \times 3-3.5 \mu \mathrm{m})$ [56]; X. macrosporus differs from $X$. laceratus by its ellipsoid to broad ellipsoid, larger basidiospores $(8-10.5 \times 7.5-9 \mu \mathrm{m})$ [32]; $X$. rhododendricola could be delimited from $X$. laceratus by its odontioid, buff-yellow hymenophore, and usually encrusted with crystals leptocystidia $(30-35 \times 3-3.5 \mu \mathrm{m})$ [3]; X. subserpentiformis is distinguishable from $X$. laceratus by its snake-like sinuous tramacystidia $(45-50 \times 4.5-5.5 \mu \mathrm{m})$ and utriform or subclavate basidia $(20-25 \times 4.5-5.5 \mu \mathrm{m})[3]$.

Xylodon montanus is similar to X. anmashanensis (Yurchenko, H.X. Xiong \& Sheng H. Wu) Riebesehl, Yurchenko \& Langer, X. brevisetus (P. Karst.) Hjortstam \& Ryvarden, X. crassisporus (Gresl. \& Rajchenb.) Hjortstam \& Ryvarden, X. gossypinus and X. pumilius in having the moniliform cystidia. However, Xylodon anmashanensis differentiates from X. montanus by its cracked, odontioid hymenophore and three kinds of cystidia: hyphoid or subulate cystidia $(22-53 \times 2.5-4.5 \mu \mathrm{m})$, moniliform and submoniliform cystidia $(20-60 \times 3-5 \mu \mathrm{m})$ [15]; X. brevisetus is diverse from $X$. montanus by its odontioid hymenophore, clavate to cylindrical basidia (20-25 $\times 4-5 \mu \mathrm{m})$ [25]; X. crassisporus could be delimited from X. montanus by its odontioid, pale yellow or very pale brown hymenophore, and the capitate cystidia $(27-75 \times 2-5 \mu \mathrm{m})$ [56]; $X$. gossypinus differs from $X$. montanus by its flocculent basidiomata and capitate cystidia $(16-23.5 \times 2.5-5 \mu \mathrm{m})$ [32]; X. pumilius is distinguishable from $X$. montanus by its ochraceous hymenophore, capitate cystidia (30-45 $\times 4-5 \mu \mathrm{m})$ and broadly ellipsoid to broadly, thick-walled basidiospores $(5-6 \times 4-5 \mu \mathrm{m})[56]$.

Xylodon tropicus is similar to Xylodon damansaraensis Xue W. Wang \& L.W. Zhou, X. septocystidiatus, X. tenellus Hjortstam \& Ryvarden, X. ussuriensis Viner and X. yarraensis in having the grandinioid hymenophore. However, Xylodon damansaraensis distinguishes from $X$. tropicus by its white hymenophore, clavate-sinuous to submoniliform cystidia 
(35-40 × 6-7 $\mu \mathrm{m})$ and narrowly ellipsoid basidiospores $(5.2-5.7 \times 2.3-3.1 \mu \mathrm{m})$ [3]; X. septocystidiatus differentiates from $X$. tropicus by its pale buff hymenophore and subcylindrical basidia with subuniform constriction $(16-22 \times 34.5-5 \mu \mathrm{m})$ [12]; X. tenellus is diverse from $X$. tropicus by its whitish hymenophore, capitate cystidia (30-60 $\mu \mathrm{m}$ long) and thin-walled basidiospores $(4 \times 4.5 \mu \mathrm{m})$ [28]; X. ussuriensis could be delimited from $X$. tropicus by its pale ochraceous hymenophore, three types of cystidia: capitate cystidia $(71.0-188.9 \times 5.7-9.4 \mu \mathrm{m})$, astrocystidia $(15-17 \times 4.5-4.8 \mu \mathrm{m})$, fusoid to cylindrical or submoniliform cystidia $(40.0-84.0 \times 5.0-9.0 \mu \mathrm{m})$, and ellipsoid to broadly ellipsoid basidiospores $(5.1-6.0 \times 3.8-4.6 \mu \mathrm{m})$ [27]; X. yarraensis is different from $X$. tropicus by its capitate cystidia $(25-30 \times 2.5-3.5 \mu \mathrm{m})$ and ellipsoid basidiospores $(4.5-5.3) \times 3.1-3.8 \mu \mathrm{m})[3]$.

Miettinen et al. [71] analyzed a higher-level phylogenetic classification of polypores and showed that the macromorphology of fruiting bodies and hymenophore construction did not reflect monophyletic groups. The current phylogeny shows that the morphological characters do not follow the phylogenetic group on different taxa in this genus. However, several characters lead the key role, e.g., the hyphal system monomitic, basidiospores ellipsoid, and thin-walled (Figure 2).

So far, 33 taxa of Xylodon were recorded in China [3,22,24,27,31,32,37,44,72]. Based on the morphological and phylogenetic study of Xylodon presented here, all of these can be delimited from our three new species (Figures 1 and 2).

Author Contributions: Conceptualization, C.-L.Z.; methodology, C.-L.Z. and M.-H.Q.; software, C.-L.Z. and M.-H.Q.; validation, C.-L.Z. and M.-H.Q.; formal analysis, C.-L.Z. and M.-H.Q.; investigation, C.-L.Z., M.-H.Q. and D.-Q.W.; resources, C.-L.Z.; writing-original draft preparation, C.-L.Z. and M.-H.Q.; writing—review and editing, C.-L.Z. and M.-H.Q.; visualization, C.-L.Z. and M.-H.Q.; supervision, C.-L.Z.; project administration, C.-L.Z.; funding acquisition, C.-L.Z. All authors have read and agreed to the published version of the manuscript.

Funding: The research was supported by the National Natural Science Foundation of China (Project No. 32170004, U2102220), Yunnan Fundamental Research Project (Grant No. 202001AS070043), and the High-level Talents Program of Yunnan Province (YNQR-QNRC-2018-111).

Institutional Review Board Statement: Not applicable.

Informed Consent Statement: Not applicable.

Data Availability Statement: Publicly available datasets were analyzed in this study. This data can be found here: [https:/ /www.ncbi.nlm.nih.gov/; https://www.mycobank.org/page/Simple\%20names\%20 search; http:/ / purl.org/phylo/treebase, submission ID 29060; accessed on 30 November 2021].

Conflicts of Interest: The authors declare no conflict of interest.

\section{References}

1. Hibbett, D.S.; Bauer, R.; Binder, M.; Giachini, A.J.; Hosaka, K.; Justo, A.; Larsson, E.; Larsson, K.H.; Lawrey, J.D.; Miettinen, O.; et al. 14: Agaricomycetes. In Systematics and Evolution; Springer: Berlin/Heidelberg, Germany, 2014; pp. $373-429$.

2. Dai, Y.C. A revised checklist of corticioid and hydnoid fungi in China for 2010. Mycoscience 2011, 52, 69-79. [CrossRef]

3. Wang, X.W.; May, T.W.; Liu, S.L.; Zhou, L.W. Towards a Natural Classification of Hyphodontia Sensu Lato and the Trait Evolution of Basidiocarps within Hymenochaetales (Basidiomycota). J. Fungi 2021, 7, 478. [CrossRef]

4. Jülich, W. Higher taxa of Basidiomycetes. Bibl. Mycol. 1981, 85, 1-485.

5. Gray, S.F. A Natural Arrangement of British Plants; Nabu Press: London, UK, 1821; pp. 1-649.

6. Bernicchia, A.; Gorjón, S.P. Fungi Europaei 12: Corticiaceae s.l.; Edizioni Candusso: Alassio, Italy, 2010; pp. 731-744.

7. $\mathrm{Wu}, \mathrm{S} . \mathrm{H}$. The Corticiaceae (Basidiomycetes) subfamilies Phlebioideae, Phanerochaetoideae and Hyphodermoideae in Taiwan. Ann. Bot. Fenn. 1990, 142, 1-123.

8. Wu, S.H. Studies on Schizopora flavipora s.l., with special emphasis on specimens from Taiwan. Mycotaxon 2000, 76, 51-66.

9. Wu, S.H. Three new species of Hyphodontia with poroid hymenial surface. Mycologia 2001, 93, 1019-1025. [CrossRef]

10. Wu, S.H. Hyphodontia tubuliformis, a new species from Taiwan. Mycotaxon 2006, 95, 185-188.

11. Xiong, H.X.; Dai, Y.C.; Wu, S.H. Three new species of Hyphodontia from Taiwan. Mycol. Prog. 2009, 8, 165-169. [CrossRef]

12. Xiong, H.X.; Dai, Y.C.; Wu, S.H. Two new species of Hyphodontia from China. Mycologia 2010, 102, 918-922. [CrossRef]

13. Dai, Y.C. Polypore diversity in China with an annotated checklist of Chinese polypores. Mycoscience 2012, 53, 49-80. [CrossRef]

14. Lee, I.S.; Langer, E. New records of Hyphodontia species from Taiwan. Nova Hedwig. 2012, 94, 239-244. [CrossRef] 
15. Yurchenko, E.; Xiong, H.X.; Wu, S.H. Four new species of Hyphodontia (Xylodon s.s. Hjortstam \& Ryvarden, Basidiomycota) from Taiwan. Nowa Hedwig. 2013, 96, 545-558. [CrossRef]

16. Yurchenko, E.; Wu, S.H. Hyphoderma formosanum sp. nov. (Meruliaceae, Basidiomycota) from Taiwan. Sydowia $2014,66,19-23$.

17. Zhao, C.L.; Cui, B.K.; Dai, Y.C. Morphological and molecular identification of two new species of Hyphodontia (Schizoporaceae, Hymenochaetales) from southern China. Cryptogam. Mycol. 2014, 35, 87-97. [CrossRef]

18. Chen, J.J.; Zhou, L.W.; Ji, X.H.; Zhao, C.L. Hyphodontia dimitica and H. subefibulata spp. nov. (Schizoporaceae, Hymenochaetales) from southern China based on morphological and molecular characters. Phytotaxa 2016, 269, 1-13. [CrossRef]

19. Chen, C.C.; Wu, S.H.; Chen, C.Y. Xylodon subflaviporus sp. nov. (Hymenochaetales, Basidiomycota) from East Asia. Mycoscience 2018, 59, 343-352. [CrossRef]

20. Kan, Y.H.; Gafforov, Y.; Li, T.; Zhou, L.W. Hyphodontia zhixiangii sp. nov. (Schizoporaceae, Basidiomycota) from Uzbekistan. Phytotaxa 2017, 299, 273-279. [CrossRef]

21. Kan, Y.H.; Qin, W.M.; Zhou, L.W. Hyphodontia mollissima sp. nov. (Schizoporaceae, Hymenochaetales) from Hainan, southern China. Mycoscience 2017, 58, 297-301. [CrossRef]

22. Riebesehl, J.; Langer, E. Hyphodontia s.l. (Hymenochaetales, Basidiomycota): 35 new combinations and new keys to all 120 current species. Mycol. Prog. 2017, 16, 637-666. [CrossRef]

23. Wang, M.; Chen, Y.Y. Phylogeny and taxonomy of the genus Hyphodontia (Hymenochaetales, Basidiomycota) in China. Phytotaxa 2017, 309, 45-54. [CrossRef]

24. Shi, Z.W.; Wang, X.W.; Zhou, L.W.; Zhao, C.L. Xylodon kunmingensis sp. nov. (Hymenochaetales, Basidiomycota) from southern China. Mycoscience 2019, 60, 184-188. [CrossRef]

25. Hjortstam, K.; Ryvarden, L. A checklist of names in Hyphodontia sensu stricto-sensu lato and Schizopora with new combinations in Lagarobasidium, Lyomyces, Kneiffiella, Schizopora, and Xylodon. Syn. Fungorum 2009, 26, 33-55.

26. Kuntze, O. Iridaceae. Revisio Generum Plantarum; A. Felix: Leipzig, Germany, 1898; pp. 1-576.

27. Viner, I.; Spirin, V.; Zíbarová, L.; Larsson, K.H. Additions to the taxonomy of Lagarobasidium and Xylodon (Bymenochaetales, Basidiomycota). Mycokeys 2018, 41, 65-90. [CrossRef]

28. Hjortstam, K.; Ryvarden, L. Studies in corticioid fungi from Venezuela III (Basidiomycotina, Aphyllophorales). Syn. Fungorum 2007, 23, 56-107.

29. Chevallier, F.F. Flore Générale des Environs de Paris; Ferra Jeune: Paris, France, 1826; pp. 1-674.

30. Tura, D.A.; Zmitrovich, I.V.; Wasser, S.P.; Spirin, W.A.; Nevo, E. Biodiversity of the Heterobasidiomycetes and Non-Gilled Hymenomycetes (Former Aphyllophorales) of Israel; ARA Gantner Verlag K-G: Ruggell, Liechtenstein, 2011; pp. 1-566.

31. Riebesehl, J.; Yurchenko, E.; Nakasone, K.K.; Langer, E. Phylogenetic and morphological studies in Xylodon (Hymenochaetales, Basidiomycota) with the addition of four new species. MycoKeys 2019, 47, 97-137. [CrossRef] [PubMed]

32. Luo, K.Y.; Qu, M.H.; Zhao, C.L. Additions to the knowledge of corticioid Xylodon (Schizoporaceae, Hymenochaetales): Introducing three new Xylodon species from southern China. Diversity 2021, 13, 581. [CrossRef]

33. James, T.Y.; Stajich, J.E.; Hittinger, C.T.; Rokas, A. Toward a fully resolved fungal tree of life. Annu. Rev. Microbiol. 2020, 74, 291-313. [CrossRef]

34. Yurchenko, E.; Wu, S.H. Three new species of Hyphodontia with peg-like hyphal aggregations. Mycol. Prog. 2013, 13, 533-545. [CrossRef]

35. Petersen, J.H. Farvekort. In The Danish Mycological Society's Colour-Chart; Foreningen til Svampekundskabens Fremme: Greve, Germany, 1996; pp. 1-6.

36. White, T.J.; Bruns, T.; Lee, S.; Taylor, J. Amplification and direct sequencing of fungal ribosomal RNA genes for phylogenetics. PCR Protoc. A Guide Methods Appl. 1990, 18, 315-322. [CrossRef]

37. Yurchenko, E.; Riebesehl, J.; Langer, E.J. Fasciodontia gen. nov. (Hymenochaetales, Basidiomycota) and the taxonomic status of Deviodontia. Mycol. Prog. 2020, 19, 171-184. [CrossRef]

38. He, S.H.; Li, H.J. Pseudochaete latesetosa and P. subrigidula spp. nov. (Hymenochaetales, Basidiomycota) from China based on morphological and molecular characters. Mycol. Prog. 2013, 12, 331-339. [CrossRef]

39. Larsson, K.H. Re-thinking the classification of corticioid fungi. Mycol. Res. 2007, 111, 1040-1063. [CrossRef] [PubMed]

40. Yurchenko, E.; Riebesehl, J.; Langer, E. Clarification of Lyomyces sambuci complex with the descriptions of four new species. Mycol. Prog. 2017, 16, 865-876. [CrossRef]

41. Chen, J.Z.; Zhao, C.L. Morphological and molecular identification of four new resupinate species of Lyomyces (Hymenochaetales) from southern China. MycoKeys 2020, 65, 101-118. [CrossRef] [PubMed]

42. Chen, C.C.; Wu, S.H.; Chen, C.Y. Three new species of Hyphodontia s.l. (Basidiomycota) with poroid or raduloid hymenophore. Mycol. Prog. 2017, 16, 553-564. [CrossRef]

43. Larsson, K.H.; Larsson, E.; Kõljalg, U. High phylogenetic diversity among corticioid homobasidiomycetes. Mycol. Res. 2004, 108, 983-1002. [CrossRef]

44. Ma, X.; Zhao, C.L. Xylodon bambusinus and X. xinpingensis spp. nov. (Hymenochaetales) from southern China. Phytotaxa 2021, 511, 231-247. [CrossRef]

45. Paulus, B.; Hallenberg, N.; Buchanan, P.K.; Chambers, G.K. A phylogenetic study of the genus Schizopora (Basidiomycota) based on ITS DNA sequences. Mycol. Res. 2000, 104, 1155-1163. [CrossRef] 
46. Vu, D.; Groenewald, M.; de Vries, M.; Gehrmann, T.; Stielow, B.; Eberhardt, U.; Al-Hatmi, A.; Groenewald, J.Z.; Cardinali, G.; Houbraken, J.; et al. Large-scale generation and analysis of filamentous fungal DNA barcodes boosts coverage for kingdom fungi and reveals thresholds for fungal species and higher taxon delimitation. Stud. Mycol. 2019, 92, 135-154. [CrossRef]

47. Larsson, K.H.; Parmasto, E.; Fischer, M.; Langer, E.; Nakasone, K.K.; Redhead, S.A. Hymenochaetales: A molecular phylogeny for the hymenochaetoid clade. Mycologia 2006, 98, 926-936. [CrossRef]

48. Hall, T.A. Bioedit: A user-friendly biological sequence alignment editor and analysis program for windows 95/98/NT. Nucleic Acids Symp. Ser. 1999, 41, 95-98.

49. Zhao, C.L.; Wu, Z.Q. Ceriporiopsis kunmingensis sp. nov. (Polyporales, Basidiomycota) evidenced by morphological characters and phylogenetic analysis. Mycol. Prog. 2017, 16, 93-100. [CrossRef]

50. Swofford, D.L. PAUP: Phylogenetic Analysis Using Parsimony (and Other Methods); Version 4.0b10; Sinauer Associates: Sunderland, MA, USA, 2002.

51. Felsenstein, J. Confidence intervals on phylogenetics: An approach using bootstrap. Evolution 1985, 39, 783-791. [CrossRef]

52. Miller, M.A.; Pfeiffer, W.; Schwartz, T. The CIPRES Science Gateway: Enabling high-impact science for phylogenetics researchers with limited resources. Assoc. Comput. Mach. 2012, 39, 1-8. [CrossRef]

53. Nylander, J.A.A. MrModeltest v2. Program Distributed by the Author; Evolutionary Biology Centre, Uppsala University: Uppsala, Sweden, 2004.

54. Ronquist, F.; Teslenko, M.; van der Mark, P.; Ayres, D.L.; Darling, A.; Hohna, S.; Larget, B.; Liu, L.; Suchard, M.A.; Huelsenbeck, J.P. Mrbayes 3.2: Efficient bayesian phylogenetic inference and model choice across a large model space. Syst. Biol. 2012, 61, 539-542. [CrossRef] [PubMed]

55. Eriksson, J.; Ryvarden, L. The Corticiaceae of North Europe. Syn. Fungorum 1976, 4, 547-886.

56. Greslebin, A.G.; Rajchenberg, M. The genus Hyphodontia in the Patagonian Andes forest of Argentina. Mycologia 2000, 92, 1155-1165. [CrossRef]

57. Kotiranta, H.; Saarenoksa, R. Three new species of Hyphodontia (Coritciaceae). Ann. Bot. Fenn. 2000, 37, $255-278$.

58. Boidin, J.; Gilles, G. Homobasidiomycètes Aphyllophorales non porés à basides dominantes à 2 (3) stérigmates. Bull. Trimest. Soc. Mycol. Fr. 2003, 119, 1-17.

59. Burdsall, H.H.; Nakasone, K.K.; Freeman, G.W. New species of Gloeocystidiellum (Corticiaceae) from the southeastern United-States. Syst. Bot. 1981, 6, 422-434. [CrossRef]

60. Langer, E. Die Gattung Hyphodontia John Eriksson. Bibl. Mycol. 1994, 154, 1-298.

61. Nordén, B.; Appelquist, T.; Lindahl, B.; Henningsson, M. Cubic rot fungi-corticioid fungi in highly brown rotted spruce stumps Mycol. Helv. 1999, 10, 13-24.

62. Hjortstam, K.; Ryvarden, L.; Itturiaga, T. Studies in corticioid fungi from Venezuela II (Basidiomycotina, Aphyllophorales). Syn Fungorum 2005, 20, 42-78.

63. Jo, J.W.; Kwag, Y.N.; Kim, N.K.; Oh, S.O.; Kim, C.S. A-33: Newly recorded macrofungal species (Xylodon flaviporus) in Dokdo, Republic of Korea. KSM Newsl. 2018, 30, 83.

64. Gilbertson, R.L.; Ryvarden, L. North American Polypores 1-2; Fungiflora: Oslo, Norway, 1987; pp. 1-433.

65. Núñez, M.; Ryvarden, L. East Asian polypores 2. Syn. Fungorum 2001, 14, 165-522.

66. Ryvarden, L.; Melo, I. Poroid fungi of Europe. Syn. Fungorum 2014, 31, 1-455.

67. Yurkov, A.; Wehde, T.; Kahl, T.; Begerow, D. Aboveground deadwood deposition supports development of soil yeasts. Diversity 2012, 4, 453-474. [CrossRef]

68. Girometta, C.E.; Bernicchia, A.; Baiguera, R.M.; Bracco, F.; Buratti, S.; Cartabia, M.; Picco, A.M.; Savino, E. An italian research culture collection of wood decay fungi. Diversity 2020, 12, 58. [CrossRef]

69. Van Bael, S.A. Fungal diversity. Diversity 2020, 12, 437. [CrossRef]

70. Ogura-Tsujita, Y.; Tetsuka, K.; Tagane, S.; Kubota, M.; Anan, S.; Yamashita, Y.; Tone, K.; Yukawa, T. Differing life-history strategies of two mycoheterotrophic orchid species associated with leaf litter- and wood-decaying fungi. Diversity 2021, 13, 161. [CrossRef]

71. Miettinen, O.; Spirin, V.; Vlasák, J.; Rivoire, B.; Stenroos, S.; Hibbett, D. Polypores and genus concepts in Phanerochaetaceae (Polyporales, Basidiomycota). MycoKeys 2016, 17, 1-46. [CrossRef]

72. Gafforov, Y.; Riebesehl, J.; Ordynets, A.; Langer, E.; Yarasheva, M.; Ghobad-Nejhad, M.; Zhou, L.W.; Wang, X.W.; Gugliotta, A.D.M. Hyphodontia (Hymenochaetales, Basidiomycota) and similar taxa from Central Asia. Botany 2017, 95, 1041-1056. [CrossRef] 